\title{
MUTU PELAYANAN TERHADAP KEPUASAN PASIEN RAWAT JALAN DI PUSKESMAS PIYUNGAN BANTUL TAHUN 2018
}

\author{
Maristha Monicha Putri ${ }^{1}$ Chanif Kurnia Sari ${ }^{2}$ \\ Stikes Surya Global Yogyakarta
}

\begin{abstract}
Health center are health service facilities that are required to provide quality, affordable, fair and equitable health services. Based on the overall outpatient waiting time of the Piyungan Bantul Public Health Center in Yogyakarta both from the registration stage, to the examination stage and the waiting stage of the drug each patient takes a long waiting time of more than one hour. The complaint mainly originated from general poly patients, because the number of patients in the general poly was classified as the most daily compared to otherpoly.

This type of research is quantitative descriptive using a cross sectional study design. The study population was 4767 patients on average month with a sample of 98 patients using the slovin formula.

Based the results of testing using the T test individually obtained the effect of tangible on patient satisfaction 0,099 $<0,05$. The influence of reliability on patient satisfaction $0,000<0,05$. The effect of responsiveness on patient satisfaction was 0,004 $<0,05$. The effect of assurance on patient satisfaction 0,001 <0,05. The influence of emphaty on patient satisfaction 0,004 $<0,05$. From the test together, the results of the influence of service quality on patient satisfaction at Public Health Center Piyungan Bantul Yogyakarta $0.000<0,05$. there is an influence of service quality (tangible, reliability, responsiveness, assurance, emphaty) on outpatient satisfaction at Public Health Center Piyungan Bantul Yogyakarta.
\end{abstract}

Keywords :Tangible, Reliability, Responsiveness, Assurance, Emphaty.

\begin{abstract}
Abstrak
Puskesmas merupakan sarana pelayanan kesehatan yang wajib menyelenggarakan pelayanan kesehatan secara bermutu, terjangkau, adil, dan merata. Berdasarkan keseluruhan waktu tunggu rawat jalan Puskesmas Piyungan Bantul Yogyakarta baik dari tahap pendaftaran, hingga tahap pemeriksaan dan tahap penungguan obat setiap pasien memakan waktu tunggu yang cukup lama lebih dari satujam.

Jenis Penelitian ini adalah deskriptif Kuantitatif dengan menggunakan rancangan penelitian Cross sectional.Populasi Penelitian sebanyak 4767 pasien rata-rata perbulan dengan sampel 98 pasien menggunakan rumus slovin.

Dari hasil pengujian menggunakan uji $\mathrm{T}$ secara sendiri-sendiri didapatkan hasil pengaruh Tangible terhadap kepuasan pasien 0,099 < 0,05. Pengaruh Reliability terhadap kepuasan pasien $0,000<0,05$. Pengaruh Responsiveness terhadap kepuasan pasien 0,004 $<0,05$. Pengaruh Assurance terhadap kepuasan pasien 0,001 <0,05. Pengaruh Emphaty terhadap kepuasan pasien $0,004<0,05$. Dari hasil pengujian menggunakan uji $\mathrm{F}$ secara bersama-sama didapatkan hasil pengaruh mutu pelayanan terhadap kepuasan pasien di Puskesmas Piyungan Bantul Yogyakarta 0,000 < 0,05. Ada pengaruh mutu pelayanan (tangible, reliability, responsiveness, assurance, emphaty) terhadap kepuasan pasien rawat jalan di Puskesmas Piyungan Bantul Yogyakarta.
\end{abstract}

Kata Kunci: Nyata, Kehandalan, Responsif, Jaminan, Empati 


\section{Pendahuluan}

Puskesmas adalah suatu unit pelayanan kesehatan yang merupakan ujung tombak dalam bidang kesehatan dasar. Penggunaan jasa pelayanan kesehatan di puskesmas menuntut pelayanan yang berkualitas tidak hanya menyangkut kesembuhan dari penyakit secara fisik akan tetapi juga menyangkut kepuasan terhadap sikap, pengetahuan dan keterampilan petugas dalam memberikan pelayanan serta tersedianya sarana dan prasarana yang memadai dan dapat memberikan kenyamanan.

Berdasarkan hasil studi pendahuluan yang dilakukan peneliti pada Selasa 13 November 2018 di Instalasi Rawat Jalan Puskesmas Piyungan Bantul Yogyakarta diketahui permasalahan dalam pelayanan kesehatan di instalasi rawat jalan melalui wawancara yang dilakukan pada 5 karyawan dan 10 pengunjung Puskesmas Piyungan Bantul Yogyakarta saat studi pendahuluan, bahwa survei kepuasan pasien instalasi rawat jalan yaitu banyaknya pasien mengeluh karena hampir di setiap tahap pelayanan, waktu tunggu yang digunakan masih terbilang cukup lama yang membuat pasien harus menunggu hingga berjamjam. Berdasarkan keseluruhan waktu tunggu rawat jalan baik dari tahap pendaftaran hingga tahap pemeriksaan dan tahap menunggu obat setiap pasien memakan waktu tunggu lebih dari satu jam.Keluhan tersebut terutama berasal dari pasien pada poli umum, karena jumlah pasien di poli umum tergolong yang paling banyak tiap harinya dibandingkan poli lainnya.

Dari hasil studi pendahuluan yang dilakukan peneliti pada karyawan dan pengunjung Puskesmas Piyungan Bantul Yogyakarta, dari hasil hasil tersebut peneliti ingin mengkaji lebih lanjut mengenai mutu pelayanan dan kepuasan pasien rawat jalan Puskesmas Piyungan Bantul Yogyakarta, maka dilakukan penelitian dengan judul "Hubungan Mutu Pelayanan dengan Kepuasan Pasien Rawat Jalan di Puskesmas Piyungan Bantul Yogyakarta Tahun 2018 ?".

\section{Tujuan Penelitian}

Untuk mengetahui "pengaruh mutu pelayanan dengan kepuasan pasien rawat jalan puskesmas Piyungan Bantul Yogyakarta Tahun 2018.

\section{Metode Penelitian}

Penelitian ini merupakan penelitian kuantitatif dengan jenis penelitian deskriptif korelatif.Penelitian ini menggunakan pendekatan cross sectional, ialah suatu penelitian untuk mempelajari dinamika kolerasi antara faktor - faktor risiko dengan efek, dengan cara pendekatan, observasi, atau penggumpulan data sekaligus pada suatu saat ( point time approach).

\section{Populasi dan Sampel}

Populasi adalah subjek misalnya manusia, yang memenuhi kriteria yang ditetapkan (Sugiono:2016). Populasi penelitian ini adalah pasien rawat jalan Puskesmas Piyungan Bantul Yogyakarta pada bulan oktober 2018 sebanyak 4767 orang. Pengambilan sampel dalam penelitian ini menggunakan rumus Slovin dengan hasil 98 responden.

\section{Teknik Pengumpulan Data}

Dalam proses pengolahan data terdapat langkah-langkah yang harus ditempuh:

1. Editing

2. Coding

3. Entry

4. Cleaning.

\section{Teknik Analisis Data}

Analisis data yaitu menggunakan Analisis Univariat digunakan untuk memberikan gambaran umum terhadap data hasil penelitian. Data pendidikan dan pengetahuan diwajibkan dalam bentuk tabel distribusi frekuensi hanya menghasilkan distribusi dan presentase 


\section{Jurnal Delima Harapan 2019}

dari tiap variabel.

Analisis bivariat adalah analisis yang dilakukan terhadap dua variabel yang diduga berhubungan atau berkorelasi Notoadmodjo (2012). Penelitian ini mencari hubungan dan membuktikan hipotesis hubungan dua variabel.

Uji T (t-test) : Digunakan untuk mengetahui keterendalan serta kemaknaan dari nilai koefisien regresi Notoadmodjo (2012), sehingga dapat diketahui apakah faktor- faktor yang mempengaruhi Tangible, Reliability, Assurance, Emphaty, Resvonsiveness (X) Kepuasan Pasien (Y) apakah signifikan atau tidak.

Analisis bivariat hanya akan menghasilkan antara dua variabel yang bersangkutan (variabel independen dan variabel dependen). Untuk mengetahui hubungan lebih dari satu variabel independen dengan satu variabel dependen, harus ditunjukan lagi dengan analisis.

Uji F (F-test)

Uji $F$ adalah pengujian terhadap koefisien regresi secara simulat, pengujian ini dilakukan untuk mengetahui pengaruh semua variabel independen yang terhadap dalam model secara bersama-sama (simultan) terhadap variabel dependen.

\section{HASIL PENELITIAN DAN \\ PEMBAHASAN:}

Tabel 1

Distribusi Karakteristik Responden Berdasarkan Jenis Kelamin Di Puskesmas Piyungan Bantul Yogyakarta.

\begin{tabular}{ccc}
\hline $\begin{array}{c}\text { Jenis } \\
\text { Kelamin }\end{array}$ & Frekuensi & Prosentase \\
\hline Laki-laki & 31 & 31,6 \\
Perempuan & 67 & 68,4 \\
\hline \multicolumn{1}{c}{ Total } & $\mathbf{9 8}$ & $\mathbf{1 0 0}$ \\
\hline
\end{tabular}

Berdasarkan tabel 1 dapat diketahui bahwa dari 98 responden, sebagian besar adalah berjenis kelamin perempuan sebanyak 67 orang $(68,4 \%)$, sedangkan sisanya adalah berjenis kelamin laki-laki sebanyak 31 orang $(31,6 \%)$.

Tabel 2

Distribusi Karakteristik Responden Berdasarkan Umur di Puskesmas Piyungan Bantul Yogyakarta.

\begin{tabular}{|c|}
\hline Frekuensi \\
\hline $15-30$ \\
\hline $31-45$ \\
\hline $46-60$ \\
\hline $61-75$ \\
\hline Total \\
\hline Berdasarkan tabel 2 terlihat \\
\hline $\begin{array}{l}\text { bahwa sebagian besar responden } \\
\text { berusia } 15-30 \quad \text { tahun yaitu }\end{array}$ \\
\hline sebanyak $\quad 44$ orang $(44,9 \%)$ \\
\hline $\begin{array}{l}\text { sedangkan presentase responden } \\
\text { terkecil yaitu pada usia } 61-75 \text { tahun } \\
\text { yaitu } 4 \text { orang }(4,1 \%) \text {, dan usia } 31-45\end{array}$ \\
\hline $\begin{array}{l}\text { tahun yaitu sebanyak } 32 \text { orang } \\
(32,7 \%) \text {, serta usia } 45-60 \text { tahun } \\
\text { yaitu sebanyak } 18 \text { orang }(18,4 \%) \text {. }\end{array}$ \\
\hline
\end{tabular}

Tabel 3

Hasil Pengaruh Mutu Pelayanan (Tangible, Reliability, Responsiveness, Assurance, Empahty) terdapat kepuasan pasien di Puskesmas Piyungan Bantul Yogyakarta.

\begin{tabular}{|c|c|c|c|c|c|}
\hline \multirow[b]{3}{*}{ Model } & \multicolumn{5}{|c|}{ coefficients $^{\mathrm{a}}$} \\
\hline & $\begin{array}{r}\text { Unstan } \\
\text { Coe }\end{array}$ & $\begin{array}{l}\text { ardized } \\
\text { ficients } \\
\end{array}$ & $\begin{array}{c}\text { Standardizied } \\
\text { Coefficients } \\
\end{array}$ & & \\
\hline & B & $\underline{\text { Std.Error }}$ & $\underline{B e t a}$ & $\underline{\mathrm{t}}$ & sig. \\
\hline 1. (Constant) & $-1,349$ & 2,533 & &,- 532 & ,596 \\
\hline Tangible &, 174 &, 105 &, 111 & 1,665 & ,099 \\
\hline Reliability & 1,317 & ,247 &, 407 & 5,330 & ,000 \\
\hline Responsiveness &, 325 &, 110 & ,198 & 2,941 & ,004 \\
\hline Assurance & 1,063 &, 319 & ,263 & 3,328 & ,001 \\
\hline Emphaty &, 706 & ,241 &, 251 & 2,935 & ,004 \\
\hline
\end{tabular}

a. Dependent Variable: Kepuasan 


\section{Jurnal Delima Harapan 2019}

Tabel 3 dapat diketahui bahwa hampir semua variabel independen secara individu tidak ada pengaruh langsung dengan variabel dependen dengan penjelasan sebagai berikut:

Tabel 3 dapat diketahui bahwa nilai signifikan dari variabel tangible (bukti langsung) lebih dari 0,05 $(0,099>0,05)$. Hal tersebut berarti bahwa variabel tangible tidak ada pengaruh terhadap variabel kepuasan pasien. Sedangkan nilai $\mathrm{t}$ hitung $=1,665$ dan $\mathrm{t}$ tabel $(98: 0,10)=1,290$ sehingga nilai $t$ hitung lebih besar dari t tabel $(1,665>1,290)$ menunjukan bahwa variabel tangible memiliki pengaruh yang berlawanan arah dengan variabel kepuasan pasien. Data pada Tabel 3menunjukkan bahwa nilai signifikan dari variabel reliability (kehandalan) kurang dari 0,05 $(0,000<$ 0,05). Hal tersebut bahwa variabel reliability ada pengaruh terhadap variabel kepuasan pasien. Sedangkan nilai $\mathrm{t}$ hitung $=5,330$ dan $\mathrm{t}$ tabel $(98$ $: 0,10)=1,290$ sehingga nilai $\mathrm{t}$ hitung lebih besar dari t tabel $(5,330>1,290)$. Nilai thitung positif menunjukan bahwa variabel reliability memiliki pengaruh yang searah dengan variabel kepuasan pasien.

Dari tabel 3 diketahui bahwa nilai signifikan dari variabel responsiveness (daya tanggap) kurang dari 0,05 $(0,004<0,05)$. Hal tersebut berarti bahwa variabel responsiveness ada pengaruh terhadap variabel kepuasan pasien. Sedangkan nilai $\mathrm{t}$ hitung $=2,941$ dan $\mathrm{t}$ tabel $(98: 0,10)=1,290$ sehingga nilai $\mathrm{t}$ hitung lebih besar dari $t$ tabel $(2,941>1,290)$. Nilai $t$ hitung positif menunjukan bahwa variabel responsiveness memiliki pengaruh yang searah dengan variabel kepuasan pasien.

Tabel 3 dapat diketahui bahwa nilai signifikan dari variabel assurance (jaminan) kurang dari 0,05
$(0,001<0,05)$. Hal tersebut berarti bahwa variabel assurance ada pengaruh terhadap variabel kepuasan pasien. Sedangkan nilai $\mathrm{t}$ hitung $=3,328$ dan $\mathrm{t}$ tabel $(98: 0,10)=1,290$ sehingga nilai $t$ hitung lebih besar dari $\mathrm{t}$ tabel $(3,328>1,290)$. Nilai $t$ hitung positif menunjukan bahwa variabel assurance memiliki pengaruh yang searah dengan variabel kepuasanpasien.

Tabel 3 bahwa nilai signifikan dari variabel emphaty (empati) kurang dari $0,05(0,004<0,05)$. Hal tersebut berarti bahwa variabel emphaty ada pengaruh terhadap variabel kepuasan pasien. Sedangkan nilai $\mathrm{t}$ hitung $=2,935$ dan $\mathrm{t}$ tabel $(98: 0,10)=1,290$ sehingga nilai $\mathrm{t}$ hitung lebih besar dari $t$ tabel $(2,935>1,290)$. Nilai $t$ hitung positif menunjukan bahwa variabel emphaty memiliki pengaruh yang searah dengan variabel kepuasan pasien.

Tabel 4

Hasil Uji F Pengaruh variabel Tangible (X1), Reliability (X2), Responsiveness (X3), Assurance (X4) dan Emphaty (X5) terhadap Kepuasan Pasien (Y)

\begin{tabular}{lllcll}
\hline & \multicolumn{5}{c}{ ANOVA $^{\mathrm{b}}$} \\
\hline & Sum of & \multicolumn{5}{c}{ Mean } \\
Model & Squares & D & Square & F & Sig. \\
\hline Regression & 474,081 & 5 & 94,816 & 32,303 & $.000^{3}$ \\
Residual & 270,041 & 92 & 2,935 & & \\
\hline Total & 744,122 & 97 & & & \\
\hline
\end{tabular}

a. Predictors: (Constant), Empati, Bukti Langsung, Daya Tanggap,

Kehandalan, Jaminan

b.Dependent Variable: Kepuasan

Berdasarkan hasil perhitungan tersebut terlihat bahwa $\mathrm{F}$ hitung $>\mathrm{F}$ tabel $(32,303>2,313)$ sehingga diketahui bahwa Ho ditolak dan $\mathrm{Ha}$ diterima yang berarti bahwa ada pengaruh antara Tangible (X1), Reliability (X2), Responsiveness (X3), Assurance (X4), Emphaty (X5) terhadap Kepuasan Pasien (Y). 


\section{Jurnal Delima Harapan 2019}

\section{PEMBAHASAN}

Berdasarkan hasil analisis pada tabel 3 dapat diketahui bahwa tangible berpengaruh tidak signifikan $(0,099>$ $0,05)$ terhadap kepuasan pasien di Puskesmas Piyungan Bantul. Hal ini menunjukan bahwa kepuasan pasien tidak dipengaruhi oleh variabel tangible. Selain itu penelitian ini juga sejalan dengan penelitian Wusko (2014) dimana variabel tangible berpengaruh negatif dan tidak signifikan terhadap kepuasan pasien.

Berdasarkan hasil analisis pada tabel 3 pada reliability terhadap kepuasan pasien didapatkan hasil yaitu $0,000<0,05$ yang menunjukan bahwa reliability berpengaruh signifikan terhadap kepuasan pasien di Puskesmas Piyungan Bantul. Penelitian ini didukung oleh penelitian Supartiningsih (2017) dengan hasil penelitian ini menunjukan bahwa Kehandalan (reliability) mempunyai pengaruh positif dan signifikan terhadap kepuasan pasien.

Berdasarkan hasil analisis pada tabel 3 pada variabel responsiveness terhadap kepuasan pasien didapatkan hasil $0,004<0,05$ yang menunjukan bahwa responsiveness berpengaruh signifikan terhadap kepuasan pasien di Puskesmas Piyungan Bantul. Penelitian ini didukung oleh penelitian Imelda (2015) yang hasilnya bahwa ketanggapan mempunyai pengaruh dan signifikan terhadap kepuasanpasien.

Berdasarkan hasil analisis pada table 3 pada assurance terhadap kepuasan pasien didapatkan hasil yaitu $0,001<0,05$ yang menunjukan bahwa assurance berpengaruh signifikan terhadap kepuasan pasien di Puskesmas Piyungan Bantul. penelitian ini juga sejalan dengan penelitian Supartiningsih (2017) hasil dari variabel assurance mempunyai pengaruh yang signifikan terhadap kepuasan pasien.

Berdasarkan hasil analisis tabel 3 pada variabel emphaty terhadap kepuasan pasien didapatkan hasil yaitu $0,004<0,05$ yang menunjukan bahwa emphaty berpengaruh signifikan terhadap kepuasan pasien di Puskesmas Piyungan Bantul. Penelitian ini didukung oleh penelitian Dewi (2016) hasil dari variabel emphaty memiliki pengaruh signifikan terhadap kepuasan pasien.

Hasil penelitian dapat diperoleh hasil bahwa semua variabel mutu (tangible, reliability, responsiveness, assurance, emphaty) memiliki pengaruh secara simultan terhadap kepuasan pasien di Puskesmas Piyungan Bantul Yogyakarta. Hal ini ditunjukan dengan diperoleh nilai $F$ hitung 32,303 sedangkan untuk menentukan nilai $\mathrm{F}$ tabel pada tingkat kesalahan 0,05 dengan $\mathrm{df}$ pembilang $=5 \mathrm{dan} \mathrm{df}$ penyebut $=92$ sehingga didapatkan $\mathrm{F}$ tabel $=2,313$. Berdasarkan hasil perhitungan tersebut terlihat bahwa $\mathrm{F}$ hitung > F tabel $(32,303>2,313)$ sehingga diketahui bahwa Ho ditolak dan Ha diterima yang berarti bahwa ada pengaruh antara Tangible (XI), Reliability (X2), Responsiveness (X3), Assurance (X4), Emphaty (X5), terhadap Kepuasan Pasien(Y).

\section{KESIMPULAN}

Berdasarkan hasil penelitian dan pembahasan seperti yang sudah dipaparkan pada bab sebelumnya maka dapat ditarik beberapa kesimpulan sebagai berikut:

1. Ada pengaruh yang signifikan antara tangible (bukti langsung) terhadap kepuasan pasien di Puskesmas Piyungan Bantul.

2. Ada pengaruh yang signifikan antara reliability (kehandalan) terhadap 
kepuasan pasien di Puskesmas Piyungan Bantul.

3. Ada pengaruh yang signifikan antara responsiveness (daya tanggap) terhadap kepuasan pasien di Puskesmas Piyungan Bantul.

4. Ada pengaruh yang signifikan antara assurance (jaminan) terhadap kepuasan pasien di Puskesmas Piyungan Bantul.

5. Ada pengaruh yang signifikan antara emphaty (empati) terhadap kepuasan pasien di Puskesmas Piyungan Bantul.

6. Ada pengaruh mutu pelayanan (tangible, reliability, responsiveness, assurance, emphaty) secara simultan terhadap kepuasan pasien di Puskesmas Piyungan Bantul ditandai dengan $F$ hitung $>F$ tabel $(32,303>2,313)$ sehingga diketahui bahwa Ho ditolak dan Ha diterima.

\section{DAFTAR PUSTAKA}

Notoatmodjo, S. 2012. Metodologi Penelitian Kesehatan. Jakarta: Rineka Cipta.

Sugiyono. 2015. Metode penelitian pendidikan pendekatan kuantitatif kualitatif dan R\&D. Bandung : Alfabeta.

Sugiyono. 2016. Metode penelitian kuantitatif kualitatif dan $R \& D$. Bandung : Alfabeta.

Muninjaya. 2015. Manajemen Mutu Pelayanan Kesehatan. Jakarta : EGC.

Purnomo. 2015. Faktor-Faktor Yang Berhubungan Dengan Kepuasan Pasien Rawat Jalan Di Puskesmas Batang III.

Junita, 2016. Hubungan Mutu Pelayanan Keperawatan Dengan Tingkat Kepuasan Pasien Rawat Inap Di Rsud Pandan Kabupaten Tapanuli Tengah.

Wusko, 2014.Pengaruh Kualitas Pelayanan Terhadap Kepuasan Pengguna Jasa Pada Rumah Sakit Umum Daerah Bangil Kabupaten
Pasuruan.

Imelda, 2015.Analisis Tingkat Mutu Pelayanan Rawat Inap Dalam

Upaya Peningkatan Kepuasan

Pasien Di RSUP Adam Malik Medan.

Supartiningsih, 2017.Kualitas Pelayanan Kepuasan Pasien Rumah Sakit 